\title{
Old Wine in a New Bottle: Are Financial Variables Omitted Variables in the Production Function?
}

\author{
Nicholas Apergis \\ Department of Banging \& Financial Management, University of Piraeus \\ 80 Karaoli \& Dimitriou Str, Piraeus 18534, Greece \\ Tel: +30-210-414-2429Ｅ-mail: napergis@unipi.gr
}

Received: August 26, $2010 \quad$ Accepted: September 7, $2010 \quad$ DOI: 10.5430/rwe.v1n1p2

\begin{abstract}
This paper examines the role of financial variables in the production function by making use of nonlinear regressions along with panel data techniques and a G7 data panel set. It offers a non-linear GMM estimator that makes use of instruments that exploit information from the levels of the variables in the production function, while it uses both one-level and two-level bootstraps to check whether the estimates are supported by the data. The results suggest that both money and credit aggregates enter significantly the aggregate production function as an input, indicating that both variables seem to facilitate the process of production.
\end{abstract}

Keywords: Money, Credit, Production Function, GMM Estimations, G7 panel

\section{Introduction}

Money has been considered mainly an explicit argument in the utility function and only a few theoretical as well as empirical attempts have treated it as a factor of production because it releases other factors from the process of distribution to that of production. Dennis and Smith (1978) argued that firms have different motives for holding money balances from individuals. Money enters the production function on the grounds that it is held not for its own shake but because it is used, among other things, as an intermediate good for the services it provides. Certain attempts have been made to consider the role of money through the production process, such as Friedman $(1956,1969)$, Levhari and Patinkin (1968), Sinai and Stokes (1972), Dornbusch and Frenkel (1973), Fischer (1974), Prais (1975), Khan and Kouri (1979), Short (1979), Subrahmanyam (1980), Simos (1981), Harkness (1984), Jansen (1985), Khan and Ahmad (1985), and Benhabib et al. (1999). In those studies real money balances are considered as an explicit input of an aggregate production function, while in Nadiri (1969) and Dennis and Smith (1978) the role of money is investigated with disaggregated production functions. In addition, Haliassos and Tobin (1989) and Fisher and Seater (1993) argue that the inclusion of money in the production function supports the absence of superneutrality of money.

Although the above studies have focused on the US economy, there exist certain studies that have investigated the same issue for the Canadian economy (You, 1981; Hasan and Mahmud, 1993, among others). Their empirical findings also show a strong role for real money balances as an explicit input of production. Other research attempts have shown that money increases economic efficiency by reducing transaction transactions costs (Moroney, 1972). According to this view, by including real money balances in the production function reduces the extent to which inputs like capital and labor can be consistent with both exchange-related activities and production activities. Within this context, Betancourt and Robles (1989) and DeLorme et al. (1995) investigate the role of money as reducing technical inefficiency in production. Both studies indicate a role for money as a factor of influencing the cost of transactions but not a role as an input of production. Finally, Chang (2002) argues that in the modern world of corporations money not only promotes production efficiency but also, by engaging in human capital as well as R\&D activities, reduces transaction costs. He introduces money directly into the production function. His results indicate that money is a key input in the production function, while higher monetary growth leads to lower economic growth.

However, there exists some criticism about the concept of money as an explicit input of production. In particular, money is not a producer good but it is a medium of exchange. This criticism is based on the fact that a medium of exchange derives its usefulness from some sort of imperfections or frictions in the market, while the basics of value and allocation can be understood assuming perfect or frictionless markets. In particular, Pierson (1971) and Davidson (1979) argue that money is not related to the other inputs of production, while it is invalid to ignore the role of other aspects of the exchange system. Fisher (1974) also diminished the role of money in the production process by examining the role of 
cash balances in the technology of transactions and argued that it is practically impossible to construct an index of money that considers the saving of resources from its use. Moreover, Ben-Zion and Ruttan (1975) and Niccoli (1975) criticized the absence of a theoretical mechanism that relates money and output through the production function approach, while Prais (1975a, 1975b) and Boyes and Kavanaugh (1979) exemplified the misspecification of money in the production function approach. Finally, Nguyen (1986) and Betancourt and Robles (1989) showed empirically the absence of any solid justification for incorporating money as an input in an aggregate production function because such a procedure cannot ameliorate both the technological character of production and the associated exchange relationships. Their results received additional support by Robles (1995).

The literature has frequently posed the question whether other financial variables, besides money supply, play a role in the production process. This interest arose both from the seminal work by Blinder and Stiglitz (1983) who favored the separation of 'credit theory' from 'money theory' and from the argument exposed by Brunner and Meltzer (1988) according to which a spectrum of assets and liabilities should be taken explicitly into consideration in the production process. The issue has been kept vivid by the puzzling choice of the appropriate monetary or financial aggregate to be used as it is argued by Rotemberg et al. (1995). On a firm level both money and credit could assist an economic unit to economize on transaction costs. The presence of credit, justified by the working capital literature (Calvo and Thoumi, 1984), is needed for optimizing cash management. In particular, credit could be used as an input to synchronize the receipt of payments for output and the disbursement of payments for other inputs of production. Betancourt and Kiguel (1988) and Betancourt and Robles (1989) though they support this role for both financial variables, their results do not provide empirical evidence in favor of their role as inputs. In addition, bank credit is considered to be a crucial factor for economic development. Countries with small banking sectors have lower levels of development. Thus, financial growth may cause economic growth by improving the allocation of savings. Seminal papers by Pagano (1993), Demetriades and Hussein (1996), Levine and Zervos (1998) and Rajan and Zingales (1998) have shown that higher initial financial development implies higher GDP growth. In addition, both the theoretical and the empirical literature emphasize the role of credit on growth via its impact on efficient capital accumulation as well as on amplifying economic cycles or crises (Detken and Smets, 2004). Financial variables could affect total factor productivity (TFP) by making possible and facilitating the invention of new, efficient production processes and goods. (Levin, 1997). Therefore, it is considered extremely intrigue to investigate which or both financial variables could be considered as explicit inputs in the production function.

The goal of this paper is to examine the role of financial variables in the aggregate production function. This paper contributes to the literature on money and output first, by using nonlinear regressions in combination with panel data techniques to obtain the parameter estimates. In addition, a secondary contribution of the paper is to employ a G7 panel and an alternative definition of money balances as credit balances for the theoretical reasons exposed above. The paper is organized as follows. Section 2 provides the justification for employed production function specification, while section 3 presents the empirical implementation of the study. Finally, section 4 presents some concluding comments and provides recommendations for further research.

\section{A production function model}

For the empirical purposes of the paper and following Boyes and Kavanaugh (1979) we make use of a CES functional form for the production function. Solow $(1957,1958)$ has also emphasized the importance of the CES specification based on small trends in factor shares of income, a fact that is consistent with the observed 'relative stability' of these shares over time. These characteristics of this particular production function specification have been supported by Rebelo (1991). Moreover, more flexible production functions, e.g. the translog production function, were not used on the grounds that this form and for variables employed in this study such as real money balances suffers from extreme multicollinearity (Moroney, 1992). Thus:

$\mathrm{Y}_{\mathrm{it}}=\mathrm{A}\left[\delta_{1} \mathrm{~L}_{\mathrm{it}}{ }^{\rho}+\delta_{2} \mathrm{~K}_{\mathrm{it}}{ }^{\rho}+\delta_{3}(\mathrm{M} / \mathrm{P})_{\mathrm{it}}{ }^{\rho}\right]^{\mathrm{v} / \rho} \mathrm{e}^{\lambda \mathrm{t}}+\varepsilon_{\mathrm{it}}$

or

$\mathrm{Y}_{\mathrm{it}}=\mathrm{A}\left[\delta_{1} \mathrm{~L}_{\mathrm{it}}{ }^{\rho}+\delta_{2} \mathrm{~K}_{\mathrm{it}}{ }^{\rho}+\delta_{3}(\mathrm{CR} / \mathrm{P})_{\mathrm{it}}{ }^{\rho}\right]^{\mathrm{v} / \rho} \mathrm{e}^{\lambda \mathrm{t}}+\varepsilon_{\mathrm{it}}$

where $\mathrm{Y}$ is real aggregate output, $\mathrm{K}$ is the aggregate capital stock, $\mathrm{L}$ is the aggregate labor supply, $\mathrm{M}$ is the measure of money balances, $\mathrm{CR}$ is the measure of credit balances, $\mathrm{P}$ is the general price level, $\mathrm{t}$ is the time trend and $\varepsilon$ is a random term. A, $\delta_{1}, \delta_{2}, \delta_{3}, \rho$, and $v$ are parameters satisfying $\mathrm{A}>0$ and $\delta_{1}, \delta_{2}, \delta_{3} \in(0,1)$, while i refers to cross-section. Arrow et al. (1961) refer to $\delta$ s as the distribution parameters, although the interpretation needs extreme caution in the case of a CES specification. We allow Hicks-neutral exogenous technological growth at rate $\lambda$ and we also assume that A and $\lambda$ are common across countries. For the empirical purposes of the study we will estimate the CES production function in a 
restricted form by imposing the restriction that $v=1$ (constant returns to scale). The hypothesis of constant returns to scale in production is consistent with theoretical arguments.

Taking logarithms of both sides in both forms of the production function yielded:

$\log Y_{\mathrm{it}}=\log \mathrm{A}+\mathrm{v} / \rho \log \left[\delta_{1} \mathrm{~L}_{\mathrm{it}}{ }^{\mathrm{\rho}}+\delta_{2} \mathrm{~K}_{\mathrm{it}}{ }^{\rho}+\delta_{3}(\mathrm{M} / \mathrm{P})_{\mathrm{it}}{ }^{\mathrm{p}}\right]+\lambda \mathrm{t}+\varepsilon_{\mathrm{it}}$

or

$\log Y_{i t}=\log \mathrm{A}+\mathrm{v} / \rho \log \left[\delta_{1} \mathrm{~L}_{\mathrm{it}}{ }^{\mathrm{p}}+\delta_{2} \mathrm{~K}_{\mathrm{it}}{ }^{\mathrm{p}}+\delta_{3}(\mathrm{CR} / \mathrm{P})_{\mathrm{it}}{ }^{\mathrm{p}}\right]+\lambda \mathrm{t}+\varepsilon_{\mathrm{it}}$

In addition, we allow for the presence of fixed effects across countries. The presence of such effects allows us to capture country-specific characteristics that could have a differential impact on aggregate output. Under the presence of fixed effects the error term in equations (1) and (1)' can be written as $\varepsilon_{\mathrm{it}}=\eta_{\mathrm{i}}+\mathrm{v}_{\mathrm{it}}$, where $\eta_{\mathrm{it}}$ captures time-invariant fixed factors in country i. Thus, we first differentiate equations (1) and (1)' in order to get rid of the fixed-effect component in the error term plus certain other numerical problems given the non-linear specification of the production function, such as, the endogeneity of some of the regressors with respect to output, some potential problems of heteroskedasticity both in time and across countries, and the fact that the error term is not necessarily white noise but may exhibit autocorrelation of the moving average form of order one due to time aggregation (Anderson and Hsiao, 1982). Thus, first-differencing and imposing the restriction that $v=1$ yielded the following non-linear expression:

$$
\begin{gathered}
\log \left(\mathrm{Y}_{\mathrm{it}} / \mathrm{Y}_{\mathrm{i}, \mathrm{t}-1}\right)=\lambda+1 / \rho \log \left\{\left[\delta_{1} \mathrm{~L}_{\mathrm{it}}^{\mathrm{\rho}}+\delta_{2} \mathrm{~K}_{\mathrm{it}}^{\mathrm{\rho}}+\delta_{3}(\mathrm{M} / \mathrm{P})_{\mathrm{it}}{ }^{\rho}\right] /\left[\delta_{1} \mathrm{~L}_{\mathrm{i}, \mathrm{t}-1}{ }^{\mathrm{\rho}}+\delta_{2} \mathrm{~K}_{\mathrm{i}, \mathrm{t}-\mathrm{1}}{ }^{\mathrm{\rho}}+\right.\right. \\
\left.\left.\delta_{3}(\mathrm{M} / \mathrm{P})_{\mathrm{i}, \mathrm{t}-\mathrm{1}}{ }^{\mathrm{\rho}}\right]\right\}+\mathrm{v}_{\mathrm{it}}-\mathrm{V}_{\mathrm{i}, \mathrm{t}-1}
\end{gathered}
$$

or

$$
\begin{gathered}
\log \left(\mathrm{Y}_{\mathrm{it}} / \mathrm{Y}_{\mathrm{i}, \mathrm{t}-\mathrm{1}}\right)=\lambda+1 / \rho \log \left\{\left[\delta_{1} \mathrm{~L}_{\mathrm{it}}{ }^{\mathrm{\rho}}+\delta_{2} \mathrm{~K}_{\mathrm{it}}{ }^{\rho}+\delta_{3}(\mathrm{CR} / \mathrm{P})_{\mathrm{it}}{ }^{\mathrm{\rho}}\right] /\left[\delta_{1} \mathrm{~L}_{\mathrm{i}, \mathrm{t}-1}{ }^{\rho}+\delta_{2} \mathrm{~K}_{\mathrm{i}, \mathrm{t}-1}{ }^{\rho}+\right.\right. \\
\left.\left.\delta_{3}(\mathrm{CR} / \mathrm{P})_{\mathrm{i}, \mathrm{t}-\mathrm{l}}{ }^{\mathrm{p}}\right]\right\}+\mathrm{v}_{\mathrm{it}}-\mathrm{V}_{\mathrm{i}, \mathrm{t}-1}
\end{gathered}
$$

For the empirical purposes of this study, the following system is estimated through the General Method of Moments (GMM) methodology:

$$
\begin{aligned}
& \operatorname{dlog} \mathrm{Y}_{\mathrm{it}}=\lambda+1 / \rho \operatorname{dlog}\left[\delta_{1} \mathrm{~L}_{\mathrm{it}}{ }^{\mathrm{\rho}}+\delta_{2} \mathrm{~K}_{\mathrm{it}}{ }^{\mathrm{\rho}}+\delta_{3}(\mathrm{M} / \mathrm{P})_{\mathrm{it}}{ }^{\rho}\right]+\mathrm{v}_{\mathrm{it}}-\mathrm{v}_{\mathrm{i}, \mathrm{t}-1} \\
& \log \mathrm{Y}_{\mathrm{it}}=\lambda+1 / \rho \log \left[\delta_{1} \mathrm{~L}_{\mathrm{it}}{ }^{\mathrm{\rho}}+\delta_{2} \mathrm{~K}_{\mathrm{it}}{ }^{\mathrm{\rho}}+\delta_{3}(\mathrm{M} / \mathrm{P})_{\mathrm{it}}{ }^{\mathrm{\rho}}\right]+\eta_{\mathrm{i}}+\mathrm{v}_{\mathrm{it}} \\
& \text { or } \\
& \mathrm{d} \log \mathrm{Y}_{\mathrm{it}}=\lambda+1 / \rho \operatorname{dlog}\left[\delta_{1} \mathrm{~L}_{\mathrm{it}}{ }^{\rho}+\delta_{2} \mathrm{~K}_{\mathrm{it}}{ }^{\rho}+\delta_{3}(\mathrm{CR} / \mathrm{P})_{\mathrm{it}}{ }^{\rho}\right]+\mathrm{v}_{\mathrm{it}}-\mathrm{v}_{\mathrm{i}, \mathrm{t}-1} \\
& \log \mathrm{Y}_{\mathrm{it}}=\lambda+1 / \rho \log \left[\delta_{1} \mathrm{~L}_{\mathrm{it}}{ }^{\mathrm{\rho}}+\delta_{2} \mathrm{~K}_{\mathrm{it}}{ }^{\mathrm{\rho}}+\delta_{3}(\mathrm{CR} / \mathrm{P})_{\mathrm{it}}{ }^{\rho}\right]+\eta_{\mathrm{i}}+\mathrm{v}_{\mathrm{it}}
\end{aligned}
$$

The system GMM estimator of the type suggested by Arellano and Bond (1991), Arellano and Bover (1995), and Blundell and Bond (1998) is employed. Estimation of this type allows us to use additional information from the levels of the variables included in the production function. Moreover, this particular methodology is highly effective to overcome problems of unobserved country-specific effects, problems associated with the bias created by lagged endogenous variables and problems of the endogeneity of regressors, typical of cross-sectional (or alternatively, time-series and cross-sectional) estimates. Once it is well-known that GMM estimation is not without problems when applied to small samples (Tauchen, 1986), we make use both one-level and two-level bootstraps to check whether point estimates and estimated standard errors are biased. The advantage of this particular approach allows for the possibility of both autocorrelation and heteroskedasticity in the disturbance term, vit - vi,t-1. Finally, this particular estimation approach avoids certain problems associated with the obvious information loss involved in transforming the data, leading to problematic instrumentation and, thus, to imprecise estimates and serious small sample biases (Ahn and Schmidt, 1995; Blundell and Bond, 1998; Blundellet al., 2000). To this end, both lagged differences and levels of the variables are used. In particular, we made use of $\Delta \log _{\mathrm{i}, \mathrm{t}-1}, \Delta \log \mathrm{K}_{\mathrm{i}, \mathrm{t}-2}, \Delta \mathrm{L}_{\mathrm{i}, \mathrm{t}-1}, \Delta \mathrm{L}_{\mathrm{i}, \mathrm{t}-2}, \Delta(\mathrm{M} / \mathrm{P})_{\mathrm{i}, \mathrm{t}-1}$ or $\Delta(\mathrm{CR} / \mathrm{P})_{\mathrm{i}, \mathrm{t}-1}, \Delta(\mathrm{M} / \mathrm{P})_{\mathrm{i}, \mathrm{t}-2}$ or $\Delta(\mathrm{CR} / \mathrm{P})_{\mathrm{i}, \mathrm{t}-2}$ as instruments for equations (3) and (3)', respectively, along with their levels for equations (4) and (4)', respectively.

\section{Empirical analysis}

\subsection{Data}

Quarterly observations for manufacturing output (Y) measured as real GDP production, labor (L) measured as number of employees, capital (K) proxied by the private capital stock, money supply (M) measured as M1, credit (CR) proxied by total private credit (including both banking and other financial institutions as well as trade credit, while government subsidies to manufacturing industries are excluded due to the difficulty to obtain such measures) to manufacturing and prices (P) measured by the GDP deflator were obtained over the 1980-2005 period for the group of G7 countries. The 
2005 time limit was based on capital stock data availability. Data (except capital) was obtained through the International Financial Statistics CD-Rom, while this on capital stocks was obtained by the World Bank's STARS database. Data for real GDP, the capital stock, real money balances (nominal money supply over the GDP deflator) and real credit balances (nominal credit over the GDP deflator) was converted at Geary-Khamis purchasing power parities. By doing this, the empirical analysis will not suffer from scale effects that usually arise from differences in currency units across countries. Finally, the DPD98 software suitable for GAUSS environment as well as the RATS software version 6.3 was used to assist the empirical objective of the paper.

\subsection{Estimation Results}

Panel unit root tests justify the employment of first-differenced instruments. Table 1 reports such panel unit root results. In particular, Choi (2001), Im et al. (2003), Bai and Ng (2003), Moon and Perron (2004), and Pesaran (2005) tests were employed and they displayed that the null hypothesis of nonstationarity is rejected at $1 \%$ only after first differencing for all the variables under consideration.

$<$ Table 1 about here>

Next, GMM results are reported in Table 2. Panel I in this table reports the CES estimates without any financial variable included in the model, while the estimates reported in Panel II the results with both financial variables are reported. Looking at these estimates, the validity of the instruments is guaranteed in both panels under the hypothesis that the residuals from equations (3) and (3)' are not serially correlated. We can observe that both the Sargan and the difference Sargan tests show no evidence against our model not the instruments employed. In other words, we cannot reject the null hypothesis that both first-differences and the levels of the instruments employed are correct. Next, the empirical findings show that the estimated value of $\rho$ is negative and statistically significant regardless of whether money or credit balances are used as inputs. This negative sign of $\rho$ implies that the elasticity of substitution between capital, labor and money or credit is greater than unity, which justifies the employment of a CES rather than, say, a Cobb-Douglas specification. The GMM estimates of $\delta$ s are positive, less than unity and statistically significant in both cases. In addition, $\lambda$ is an estimate of the exogenous average growth rate of real output. A positive (negative) sign indicates that for our G7 sample and over the period under investigation the log of real output (real GDP) gas, on average, increased (declined). The estimates of $\lambda$ shown in Table 2 are positive, statistically significant, and in line with a growth rate of 3.1 percent when money balances are considered as an input (Panel II) and 3.7 percent when credit balances are used as an input (Panel II). These figures are consistent with the characteristics of the sample period in which the $\mathrm{G} 7$ group countries were marked, on average, by high productivity growth (Greenwood and Yorukoglu, 1997). Coming to the crux estimations of our study we can behold that the estimates of $\delta 3$ coefficients are positive and statistically significant under both financial variables (although the impact of credit seems to be stronger) and in both panels. Finally, a goodness of fit measure for all three alternative models is also provided. This measure displays the squared correlation between the predicted level of real output and the actual real output. This squared correlation is equivalent to the standard R2 for OLS regressions and has been suggested as a goodness of fit measure for instrumental variables (IV) regressions (Windmeijer, 1995). Its significance is tested through modified Newey-West standard errors for panel data by estimating only correlations between lagged residuals in the same cluster (Petersen, 2005). The results suggest that all models have reasonably explanatory power. However, the production function models with either financial variable display an improvement in the goodness of fit, with the case of the credit variable to showing larger improvement.

\section{$<$ Table 2 about here $>$}

\section{Concluding Remarks}

This paper offers a different methodological proposal to investigate the role of financial variables, i.e. money and credit, in production. To this end, a panel sample of the G7 countries along with a non-linear CES production function is used. Methodologically, the paper focused on the problems of information loss and small sample inference when estimating dynamic panels. To this end, a non-linear GMM estimator was employed that makes use of instruments that exploit information from the levels of the variables that appear in the production function, while the study used both one-level and two-level bootstraps to conduct inference and to check whether the estimates are supported by the data. The results suggest that both money and credit aggregates enter significantly the aggregate production function as inputs, indicating that both variables seem to facilitate the process of production.

A suggested channel for further research would be to investigate for the same country panel the mechanism(s) through which both financial variables exert a significant impact on production, such as their impact on technical efficiency of production. Moreover, the research could be expanded to include non-G7 nations or a wider time frame to periods of pre-1980 or post 2002 . 


\section{Acknowledgements}

The author wishes to thank the participants of the 'Monetary Theory and Policy' session over the Academy of Economics and Finance meetings held in Nashville, Tennessee, February 2008 and especially William Sackley (the discussant of the paper) for valuable comments and suggestions made on an earlier draft of the paper. In addition, the author is grateful to John Moroney for also making valuable comments and suggestions by reading the paper. Finally, the author is grateful to a reviewer of this journal for additional points and suggestions. Needless to say, the usual disclaimer applies.

\section{References}

Ahn, Seung, C. \& Schmidt, Peter (1995). Efficient estimation of model for dynamic panel data. Journal of Econometrics, $68,5-28$.

Anderson, T. W. \& Hsiao, Cheng (1982). Formulation and estimation of dynamic models using panel data. Journal of Econometrics, $18,47-82$.

Arellano, M. \& Bond, S. (1991). Some tests of specification for panel data: Monte Carlo evidence and an application to employment equations. Review of Economic Studies, 58, 277-297.

Arellano, M. \& Bover, O. (1995). Another look at the instrumental variable estimation of error-components models. Journal of Econometrics, 68, 29-51.

Arrow, K. J., Chenery, H. B., Minhas, B. S., \& Solow, Robert, M. (1961). Capital-labor substitution and economic efficiency. Review of Economics and Statistics, 43, 225-250.

Bai, J. \& Ng, S. (2004). A panic attack on unit root and cointegration. Econometrica, 72, 1991-2021.

Benhabib, J., Schmitt-Grohe, S. \& Uribe, M. (1999). Chaotic interest rate rules. Mimeo.

Ben-Zion, U. \& Ruttan, V. W. (1975). Money in the production function: an interpretation of empirical results. Review of Economics and Statistics, 57, 246-247.

Betancourt, R. \& Kiguel, M. (1988). Credit, money and production. Mimeo, University of Maryland, College Park.

Betancourt, R. R. \& Robles, B. J. (1989). Credit, money and production: empirical evidence. Review of Economics and Statistics, 71, 712-717.

Blinder, A. \& Stiglitz, J. (1983). Money, credit constraints and economic activity. American Economic Review, 73, 297-302.

Blundell, R. \& Bond, S. (1998). Initial conditions and moments restrictions in dynamic panel data models. Journal of Econometrics, 87, 115-143.

Blundell, R., Bond, S. \& Windmeijer, F. (2000). Estimation in dynamic panel data models: improving on the performance of the standard GMM estimator. In Nonstationary Panels, Panel Cointegration, and Dynamic Panels, edited by B. Baltagi, Amsterdam: Elsevier Sciences.

Boyes, W. J. \& Kavanaugh, D. C. (1979). Money and the production function: a test of specification errors. Review of Economics and Statistics, 61, 442-446.

Brunner, K. \& Meltzer, A. (1988). Money and credit in the monetary transmission process. American Economic Review, 78, 446-451.

Calvo, G. A. \& Thoumi, F. E. (1984). Demand fluctuations: inventories and capacity utilization. Southern Economic Journal, 50, 743-754.

Chang, W. Y. (2002). Examining the long-run Effect of money on economic growth: an alternative view. Journal of Macroeconomics, 24, 81-102.

Choi, I. (2001). Unit root tests for panel data. Journal of International Money and Banking, 20, 249-272.

Davidson, P. (1979). Money as a factor of production: ultimate neoclassical theory or Keynesian insight? a rejoinder. Journal of Post-Keynesian Economics, 2, 280-282.

DeLorme, C. D., Jr, Thompson, H. G., Jr \& Warren, R. S., Jr. (1995). Money and production: a stochastic frontier approach. The Journal of Productivity Analysis, 6, 333-342.

Demetriades, P. \& Hussein, K. (1996). Does financial development cause economic growth? time-series evidence from 16 countries. Journal of Development Economics, 51, 387-411. 
Dennis, E. \& Smith, K. V. (1978). A neoclassical analysis of the demand for real cash balances by firms. Journal of Political Economy, 86, 793-813.

Detken, C. \& Smets, F. (2004). Asset price booms \& monetary policy. ECB Working Paper No. 364, ECB, Frankfurt.

Dornbusch, R. \& Frenkel, J. A. (1973). Inflation and growth: alternative approaches. Journal of Money, Credit, and Banking, 5, 141-156.

Fischer, M. E. \& Seater, J. J. (1993). Long-run neutrality and superneutrality in an ARIMA framework. American Economic Review, 83, 402-415.

Fischer, S. (1974). Money and the production function. Economic Inquiry, 12, 517-533.

Friedman, M. (1956). Studies in the quantity theory of money. Chicago: University of Chicago Press.

Friedman, M. (1969). The optimum quantity of money and other essays. Chicago: Aldine.

Greenwood, J. \& Yorukoglu, M. (1997). 1974. Carnegie-Rochester Conference Series on Public Policy, 46, 49-95.

Haliassos, M. \& Tobin, J. (1989). The macroeconomics of government finance. In Friedman, B. and Hahn, F. (Eds.), Handbook of monetary economics. Amsterdam: North Holland Publishing Co.

Harkness, J. (1984). Optimal exchange intervention for a small open economy. In Bhandari, Jagdeep, S. and Turnovsky, Stephen, J. (Eds.) Exchange rate management under uncertainty. Cambridge, Massachussets.

Hasan, A. M. \& Mahmud, S. F. (1993). Is money an omitted variable in the production function? some further results. Empirical Economics, 18, 431-445.

Im, K. S., Pesaran, H. M. \& Shin, Y. (2003). Testing for unit roots in heterogeneous panels. Journal of Econometrics, $115,53-74$.

Jansen, D. W. (1985). Real balances in an ad hoc Keynesian model and policy ineffectiveness. Journal of Money, Credit and Banking, 17, 378-386.

Khan, A. H. \& Ahmad, M. (1985). Real money balances in the production function of a developing country. Review of Economics and Statistics, 67, 336-340.

Khan, M. S. \& Kouri, P. J. K. (1975). Real money balances as a factor of production: a comment. Review of Economics and Statistics, 57, 244-246.

Levhari, D. L. \& Patinkin, D. (1968). The role of money in a simple growth Model. American Economic Review, 58, 713-753.

Levine, R. \& Zervos, S. (1998). Stock markets, banks, and economic growth. American Economic Review, 88, 537-558.

Levine, R. (1997). Financial development and economic growth: views and agenda. Journal of Economic Literature, 35, 688-726.

Moon, R. H. \& Perron, B. (2004). Testing for a unit root in panels with dynamic factors. Journal of Econometrics, 122, $81-126$.

Moroney, J. R. (1972). The current state of money and production theory. American Economic Review, Papers and Proceedings, 62, 335-343.

Moroney, J. R. (1992). Energy, capital, and technological change in the United States. Resources and Energy, 14, 363-380.

Nadiri, I. M. (1969). The determinants of real cash balances in the U.S. total manufacturing sector. Quarterly Journal of Economics, 83, 173-196.

Nguyen, H. V. (1986). Money in the aggregate production function: reexamination and further evidence. Journal of Money, Credit, and Banking, 18, 141-151.

Niccoli, A. (1975). Real money balances: an omitted variable from the production function? a comment. Review of Economics and Statistics, 57, 241-243.

Pagano, M. (1993), Financial markets and growth: an overview. European Economic Review, 37, 613-622.

Pesaran, H. M. (2005). A simple panel unit root test in the presence of cross section dependence. Mimeo, Cambridge University.

Petersen, M. A. (2005). Estimating errors in finance panel data: comparing approaches. NBER Working Paper No 11280, Massachusetts.

Pierson, G. (1971). The role of money in economic growth. Quarterly Journal of Economics, 86, 385-395. 
Prais, Z. (1975a). Real money balances as a variable in the production function. Review of Economics and Statistics, 57, 243-244.

Prais, Z. (1975b). Real money balances as a variable in the production function. Journal of Money, Credit, and Banking, 7, 535-544

Rajan, R. \& Zingales, L. (1998). Financial dependence and growth. American Economic Review, 88, 559-586.

Rebelo, S. (1991). Long-run policy analysis and long-run growth. Journal of Political Economy, 99, 500-521.

Robles, B. (1995). Finance capital in dynamic factor demand models. Applied Economics, 27, 431-440.

Rotemberg, J. J., Driscoll, J. C. \& Poterba, J. J. (1995). Money, output, and prices: evidence from a new monetary aggregate. Journal of Business and Economic Statistics, 13, 67-83.

Short, E., Eugenie, D. \& Dudding, R. (1979). A new look at real money balances as a variable in the production function. Journal of Money, Credit, and Banking, 11,326-339.

Simos, E. O. (1981). Real money balances as a productive input. Journal of Monetary Economics, 7, 207-225.

Sinai, A. \& Stokes, H. H. (1975). Real money balances: an omitted variable from the production function?. Review of Economics and Statistics, 54, 290-296.

Solow, R. M. (1957). Technical change and the aggregate production function. Review of Economics and Statistics, 39, 312-320.

Solow, R. M. (1958). A skeptical note on the constancy of relative shares. American Economic Review, 48, 618-631.

Subrahmanyam, G. (1980). Real money balances as a factor of production: some New evidence. Review of Economics and Statistics, 62, 280-283.

Tauchen, G. (1986). Statistical properties of GMM estimators of structural parameters obtained from financial market data. Journal of Business and Economic Statistics, 4, 397-416.

Windmeijer, F. (1995). A note on $\mathrm{R}^{2}$ in the instrumental variables model. Journal of Quantitative Economics, 11, 257-261.

You, J. S. (1981). Money, technology, and the production function: an empirical study. Canadian Journal of Economics, $14,515-524$

Table 1. Panel Unit Root Tests

\begin{tabular}{|c|c|c|c|c|c|c|c|}
\hline \multirow{3}{*}{$\begin{array}{c}\text { Variables } \\
Y\end{array}$} & \multicolumn{7}{|c|}{ Tests } \\
\hline & \multirow{2}{*}{$\begin{array}{c}\text { IPS } \\
-1.46(2)\end{array}$} & \multirow{2}{*}{$\begin{array}{c}\text { Choi } \\
-0.76\end{array}$} & \multirow{2}{*}{$\begin{array}{c}\text { Pesaran } \\
-0.68\end{array}$} & \multirow{2}{*}{$\begin{array}{c}\text { Bai \& Ng } \\
-0.79\end{array}$} & \multicolumn{3}{|c|}{ Moon and Perron } \\
\hline & & & & & -0.85 & -0.76 & {$[\mathrm{r}=4]$} \\
\hline$\Delta \mathbf{Y}$ & $-4.53(1)^{*}$ & $-3.49^{*}$ & $-3.41^{*}$ & $-3.41 *$ & $-5.42 *$ & $-5.24 *$ & \\
\hline $\mathbf{K}$ & $-1.75(3)$ & -1.03 & -0.72 & -0.82 & -0.69 & -0.62 & {$[\mathrm{r}=4]$} \\
\hline$\Delta K$ & $-4.38(2)^{*}$ & $-3,77^{*}$ & $-3.59 *$ & $-3.11 *$ & $-6.08^{*}$ & $-5.73 *$ & \\
\hline $\mathbf{L}$ & $-1.62(2)$ & -0.84 & -0.75 & -0.63 & -1.23 & -1.14 & {$[\mathrm{r}=4]$} \\
\hline$\Delta \mathbf{L}$ & $-4.19(1)^{*}$ & $-3.58^{*}$ & $-3.29 *$ & $-3.47 *$ & $-6.42 *$ & $-6.11 *$ & \\
\hline$(\mathbf{M} / \mathbf{P})$ & $-2.03(2)$ & -0.62 & -0.59 & -0.72 & -0.97 & -0.79 & {$[\mathrm{r}=4]$} \\
\hline$\Delta(\mathbf{M} / \mathbf{P})$ & $-5.16(1)^{*}$ & $-3.82 *$ & $-3.08^{*}$ & $-3.29 *$ & $-6.53 *$ & $-6.18^{*}$ & \\
\hline$(\mathrm{CR} / \mathrm{P})$ & $-1.87(3)$ & -0.50 & -0.84 & -0.58 & -1.11 & -0.98 & {$[\mathrm{r}=4]$} \\
\hline$\Delta(\mathrm{CR} / \mathrm{P})$ & $-4.55(2)^{*}$ & $-3.52 *$ & $-3.47^{*}$ & $-3.17 *$ & $-6.12 *$ & $-5.94 *$ & \\
\hline
\end{tabular}

IPS is the Im et al. (2003) test; Choi is the inverse normal test; Pesaran is the mean of individual cross-sectionally ADF statistics test; Bai \& Ng is the common factor ADF test; and Moon and Perron are the $\mathrm{t} \mathrm{a}^{*}$ and $\mathrm{t} \mathrm{b}^{*}$ tests, respectively, computed with a Barlett kernel function with a window $r=4$. Figures in parentheses denote the number of lags for the ADF test.

* Significant at the 1 percent level. 
Table 2. Nonlinear GMM regression estimates

\begin{tabular}{|c|c|c|}
\hline \multicolumn{3}{|c|}{ Panel I. CES Estimations without financial variables } \\
\hline \multirow[t]{2}{*}{$\delta_{1}$} & 0.416 & \\
\hline & $(4.11)^{*}$ & \\
\hline \multirow[t]{2}{*}{$\boldsymbol{\delta}_{2}$} & 0.238 & \\
\hline & $(3.96)^{*}$ & \\
\hline \multirow[t]{2}{*}{$\rho$} & -0.297 & \\
\hline & $(4.58)^{*}$ & \\
\hline \multirow[t]{2}{*}{$\lambda$} & 0.0297 & \\
\hline & $(4.77)^{*}$ & \\
\hline S (p-val) & 0.318 & \\
\hline dS (p-val) & 0.304 & \\
\hline Goodness of fit & $0.189[0.0367]$ & \\
\hline \multicolumn{3}{|c|}{$\left[_{\text {Corr(actualY, predictedY) }}{ }^{2}\right.$} \\
\hline \multicolumn{3}{|c|}{ Panel II. CES estimations with financial variables [equations (4) and (4') } \\
\hline & Money Balances & Credit Balances \\
\hline \multirow[t]{2}{*}{$\delta_{1}$} & 0.468 & 0.491 \\
\hline & $(3.82)^{*}$ & $(4.75)^{*}$ \\
\hline \multirow[t]{2}{*}{$\delta_{2}$} & 0.269 & 0.275 \\
\hline & $(3.77)^{* *}$ & $(3.89)^{*}$ \\
\hline \multirow[t]{2}{*}{$\delta_{3}$} & 0.048 & 0.066 \\
\hline & $(2.11)^{* * *}$ & $(3.12)^{*}$ \\
\hline \multirow[t]{2}{*}{$\rho$} & -0.336 & -0.384 \\
\hline & $(3.26)^{*}$ & $(3.95)^{*}$ \\
\hline \multirow[t]{2}{*}{$\lambda$} & 0.0313 & 0.0372 \\
\hline & $(5.86)^{*}$ & $(5.04)^{*}$ \\
\hline S (p-val) & 0.350 & 0.409 \\
\hline dS (p-val) & 0.326 & 0.385 \\
\hline Goodness of fit & $0.189[0.0367]$ & $0.312[0.0362]$ \\
\hline
\end{tabular}

The figures are the second step GMM point estimates. The figures in parentheses denote bootstrapped t-statistics. $\mathrm{S}$ denotes the Sargan test and dS denotes the difference Sargan test, while p-val is the calculated p-value from the bootstrapped distributions of the Sargan test statistic and difference Sargan test statistic. The null hypothesis is that the instruments are correct for $\mathrm{S}$ and that the level instruments are correct for $\mathrm{dS}$. The goodness-of-fit measure is the squared correlation coefficient between actual and predicted levels of the dependent variable. Figures in brackets denote modified Newey-West asymptotic standard errors for panel data (Petersen, 2005).

* significant at the 1 percent level

** significant at the 5 percent level

*** significant at the 10 percent level 